\title{
Serum biochemistry profile determination for wild loggerhead sea turtles nesting in Campos dos Goytacazes, Rio de Janeiro, Brazil
}

\author{
Determinação do perfil bioquímico sérico de tartarugas marinhas de vida livre da espécie em nidação \\ em Campos dos Goytacazes, Rio de Janeiro, Brasil
}

\author{
Daphne Wrobel Goldberg, ${ }^{\mathrm{III}}$ Juçara Wanderlinde ${ }^{\mathrm{II}}$ Isabel Maria Alexandre Freire ${ }^{\mathrm{III}}$ \\ Luiz Cesar Pereira da Silva ${ }^{\mathrm{III}}$ Nadia Regina Pereira Almosny ${ }^{\mathrm{IV}}$
}

\section{ABSTRACT}

Sea turtles are threatened to the point of extinction. The major goal of rehabilitating sick individuals is to eventually reintroduce them back into their habitat. In this way, they contribute to species preservation, as well as maintaining equilibrium of the ecosystems. Biochemical analysis is a commonly used test to detect illness and evaluate the general health of the animals. However, the data in the literature on sea turtles are scarce and the majority of studies used small sample sizes, being the majority of animals in captivity. The aim of the present study is to establish baseline biochemical profile values for free-ranging, nesting, female loggerhead turtles (Caretta caretta). The baseline values can then be used for comparison in the overall evaluation, physiologic status and disease diagnostics of diverse populations of sea turtles. Twenty-eight females in their reproductive period were used from Farol de São Thomé $\left(21^{\circ} 45^{\prime} 15^{\prime \prime} S-41^{\circ} 19^{\prime} 28^{\prime \prime} \mathrm{W}\right)$, city of Campos dos Goytacazes, north-fluminense region. The samples were collected without anticoagulant through venapuncture of the dorsal, cervical sinus. The average values determined were calcium, phosphorus, cholesterol and triglycerides, demonstrating a correlation with vitellogenesis and egg formation. The fact that females reduce feeding in the period preceding egg laying, influenced the average concentration of urea (35.25mg dL $\left.L^{-1}\right)$, sodium $\left(147 \mathrm{mEq} \mathrm{L}^{-1}\right)$, potassium $(28 \mathrm{mEq}$ $\left.L^{-1}\right)$, uric acid $\left(0.6 \mathrm{mg} d L^{-1}\right)$ and lipids. Carapace length and width, and the weight of the turtles showed a positive correlation with liver enzymes ALT and AST, suggesting that animals with larger hepatic volume have greater enzymatic activity.

Key words: Caretta caretta, reproduction, sea turtle, serum biochemistry.

\section{RESUMO}

As tartarugas marinhas são animais ameaçados de extinção. Sendo assim, o maior objetivo em reabilitar os individuos doentes é posteriormente reintroduzi-los em seu habitat. Dessa forma, contribui-se para a preservação das espécies e para a manutenção do equilíbrio dos ecossistemas. As análises bioquímicas são exames bastante utilizados na detecção de doenças e na avaliação do estado geral dos animais. Apesar disso, os dados na literatura para tartarugas marinhas ainda são escassos, e a maioria dos estudos utiliza um pequeno número de animais, sendo a maior parte deles de cativeiro. $O$ presente estudo tem por objetivo realizar o perfil bioquimico de indivíduos do sexo feminino de tartarugas marinhas de vida livre da espécie Caretta caretta em processo de nidação, bem como estabelecer a correlação do perfil bioquímico destes animais com seu tamanho. Os valores médios obtidos poderão ser utilizados posteriormente como comparativo para avaliação do estado geral e para o diagnóstico de doenças de diversas populações de tartarugas marinhas. Foram utilizadas 28 fêmeas em periodo reprodutivo, em Farol de São Thomé $\left(21^{\circ} 45^{\prime} 15^{\prime \prime} S-41^{\circ} 19^{\prime} 28^{\prime \prime} \mathrm{W}\right)$, no municipio de Campos dos Goytacazes, região norte-fluminense. As amostras foram coletadas sem anticoagulante, através de venopunção do seio venoso cervical dorsal. Os valores médios encontrados para as variáveis cálcio, fósforo, colesterol e triglicerídeos demonstram a correlação desses componentes com o processo de vitelogênese e a formação do ovo. O fato de as fêmeas reduzirem a alimentação, no período que antecede a postura dos ovos, influenciou a concentração média de uréia $(35,25 \mathrm{mg}$ $\left.d L^{-1}\right)$, sódio $\left(147 m E q L^{-1}\right)$, potássio, ácido úrico e lipídios. As variáveis vinculadas ao tamanho das tartarugas apresentaram

'Departamento de Bioquímica, Universidade Estadual do Rio de Janeiro (UERJ), Av. 28 de setembro, 87 Fds, 4 Andar, Vila Isabel, 20551-030, Rio de Janeiro, RJ, Brasil. E-mail: daphne@tamar.org.br. Autor para correspondência.

"Fundação Centro Brasileiro de Proteção e Pesquisa das Tartarugas Marinhas (Fundação Pró-Tamar), Campos dos Goytacazes, RJ, Brasil.

"IILaboratório de Experimentação Animal de Bio-Manguinhos, Rio de Janeiro, RJ, Brasil.

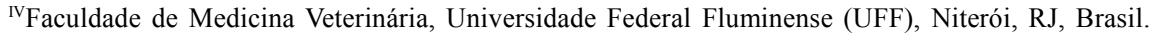


correlação positiva com enzimas ALT e AST, sugerindo que animais com maior volume hepático apresentam maior atividade enzimática.

Palavras-chave: Caretta caretta, bioquimica sérica, reprodução, tartaruga marinha.

\section{INTRODUCTION}

The first sea turtles appeared in the late Jurassic, about 65 million years ago. They have adapted their anatomical features to life in the marine environment. Nowadays there are seven living species of sea turtles worldwide. Five of the seven species are found in Brazilian waters: Lepidochelys olivacea (olive ridley), Eretmochelys imbricata (hawksbill), C. caretta (loggerhead), Chelonia mydas (green) and Dermochelys coriacea (leatherback) (BAPTISTOTTE et al., 2003).

Throughout their highly migratory lifecycles, sea turtles play important ecological roles in the marine and terrestrial ecosystems. If these reptiles were to become extinct, the negative impacts on the environment would be potentially significant (BJORNDAL \& JACKSON, 2003).

Loggerheads can be found in temperate, tropical and sub-tropical areas from both hemispheres. In Brazil, about $80 \%$ of nests belong to this species (BAPTISTOTTE et al., 2003). The reproductive range of $\boldsymbol{C}$. caretta on the Brazilian coast extends from Rio de Janeiro to Sergipe States (MARCOVALDI \& CHALOUPKA, 2007).

The data in the literature about sea turtles biochemical analyses are scarce and most of the studies used small sample sizes, being the majority of animals in captivity (KAKIZOE et al., 2007). According to CAMPBELL (1996), variables including sampling site, gender, age, diet and seasonal changes will influence blood parameters. Beyond that, comparisons among studies are hindered by the differences in analytical techniques.

The present study aimed to establish baseline biochemical profile values for free-ranging nesting female loggerheads, and to correlate these parameters with the size of animals.

\section{MATERIAL AND METHOD}

Twenty-eight nesting females were sampled

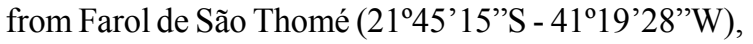
city of Campos dos Goytacazes, Rio de Janeiro, between November 2004 and January 2005. The region is characterized by the presence of restinga habitat, which consists of low lying salt-tolerant vegetation on coarse sandy soils. Campos dos Goytacazes has a wet and dry tropical climate, with average annual temperatures between $20^{\circ} \mathrm{C}$ and $32^{\circ} \mathrm{C}$, and a average annual rainfall of $1300 \mathrm{~mm}$, unevenly distributed through the year (FEEMA, 1993). The turtles received physical examination and then, were tagged with Inconel metal tags on the front flippers, measured (curved carapace length-CCL and curved carapace width-CCW) with a flexible tape measure, and weighed during egg laying; a digital scale Oswaldo Filizola, model BI-100 D (Técnica Industrial Oswaldo Filizola Ltda., São Paulo, Brazil), with a maximum capacity of $500 \mathrm{~kg}$, was used for weighting.

Five milliliters of blood were collected from the dorsal cervical venous sinus into tubes without anticoagulant and kept at room temperature for 20-30 minutes to allow complete clot formation and retraction. The whole blood was centrifuged at $560 \mathrm{~g}$ for 10 minutes, and then the serum was separated and frozen at $-20^{\circ} \mathrm{C}$ for subsequent biochemical analysis. The samples were processed within 15 days of blood collection.

Both serum and plasma samples could be employed for all the assays carried out. However, serum was preferred because of its convenience and lower cost. Additionally, in plasma samples, the total protein is $3 \%$ to $5 \%$ higher due to the presence of fibrinogen (KRATZ et al., 2002), which could possibly interfere with the results.

The biochemistry analyses were processed at $\mathrm{CAD}$ (Centro de Apoio e Diagnóstico Veterinário) in Rio de Janeiro. Blood biochemistry variables urea, creatinine, ALT (Alanine aminotransferase), AST (Aspartate aminotransferase), GGT (Gamma-glutamyl transferase), ALP (Alkaline phosphatase), cholesterol and triglycerides, were processed on Ciba Express $550^{\circledR}$ autoanalyzer. The calcium values were obtained through Bio $2000^{\circledR}$ semi automatic analyzer. The biochemical kits used for all tests were from Bio Técnica ${ }^{\circledR}$ provided by Quality SA. Sodium and potassium dosages were determined by flame photometer Corning series $400^{\circledR}$.

\section{RESULTS AND DISCUSSION}

Mean, standard deviation and degree of variance were performed for each parameter using Microsoft Excel ${ }^{\mathbb{R}}$ (Table 1). An evaluation was made of the linear relationship between biochemical parameters and turtle's size using the Pearson and Spearman's coefficients, with assistance from SPSS ${ }^{\circledR}$ software. The average weight was $119.2 \mathrm{~kg}$, average CCL was $101 \mathrm{~cm}$ and average $\mathrm{CCW}$ was $92.5 \mathrm{~cm}$ (Table 2). 
Table 1 - Mean, standard deviation, minimum and maximum reference interval of the biochemical profile of free-ranging nesting females $\boldsymbol{C}$. caretta $(\mathrm{n}=28)$, Campos of Goytacazes, RJ.

\begin{tabular}{|c|c|c|c|c|}
\hline Biochemical Parameters & Mean & Standard Deviation & Minimum & Maximum \\
\hline Urea $\left(\mathrm{mg} \mathrm{dL}^{-1}\right)$ & 35.25 & 13.50 & 11 & 70 \\
\hline Creatinine & 0.50 & 0.15 & 0.2 & 0.9 \\
\hline $\operatorname{ALT}\left(\mathrm{U} \mathrm{L}^{-1}\right)$ & 14 & 6.35 & 2 & 26 \\
\hline $\operatorname{AST}\left(\mathrm{UI} \mathrm{L}^{-1}\right)$ & 151.25 & 61.86 & 46 & 330 \\
\hline $\operatorname{ALP}\left(\mathrm{UI} \mathrm{L}^{-1}\right)$ & 13.53 & 4.69 & 4 & 25 \\
\hline GGT (UI L $\left.{ }^{-1}\right)$ & 0.72 & 0.67 & 0.1 & 2.4 \\
\hline Cholesterol (mg dL $\left.\mathrm{m}^{-1}\right)$ & 247.75 & 48.52 & 145 & 317 \\
\hline Triglicerydes $\left(\mathrm{mg} \mathrm{dL}^{-1}\right)$ & 580.28 & 232.08 & 143 & 995 \\
\hline $\mathrm{TP}\left(\mathrm{g} \mathrm{dL}^{-1}\right)$ & 3.96 & 0.72 & 2.3 & 5.3 \\
\hline Albumine $\left(\mathrm{g} \mathrm{dL}^{-1}\right)$ & 1.30 & 0.40 & 0.5 & 2.1 \\
\hline Globuline $\left(\mathrm{g} \mathrm{dL}^{-1}\right)$ & 2,66 & 0.59 & 1.4 & 3.7 \\
\hline $\mathrm{A}: \mathrm{G}$ & 0.51 & 0.20 & 0.15 & 1 \\
\hline Phosphorus (mg dl ${ }^{-1}$ ) & 7.96 & 1.85 & 3.9 & 12.1 \\
\hline Calcium $\left(\mathrm{mg} \mathrm{dl}^{-1}\right)$ & 9.98 & 1.11 & 7.9 & 12.9 \\
\hline $\mathrm{Ca}: \mathrm{P}$ & 1.33 & 0.41 & 0.77 & 2.4 \\
\hline Amylase (UI L $\left.{ }^{-1}\right)$ & 627.75 & 232.93 & 311 & 1112 \\
\hline Sodium $\left(\mathrm{mEq} \mathrm{L}^{-1}\right)$ & 147.28 & 14.05 & 108 & 168 \\
\hline Potassium $\left(\mathrm{mEq} \mathrm{L} \mathrm{L}^{-1}\right)$ & 4.27 & 0.91 & 2 & 6.6 \\
\hline Uric Acid $\left(\mathrm{mg} \mathrm{dL}^{-1}\right)$ & 0.62 & 0.21 & 0.3 & 1.2 \\
\hline
\end{tabular}

The average values for total protein reported here $\left(3.9 \mathrm{~g} \mathrm{dL}^{-1} \pm 0.72\right)$ fall within the range found by GICKING et al. (2004), for $\boldsymbol{C}$. Caretta, and by AGUIRRE \& BALAZS (2000) for $\boldsymbol{C}$. mydas. However, serum albumin values $\left(1.3 \mathrm{~g} \mathrm{dL}^{-1} \pm 0.40\right)$ were higher than those found by WHITAKER \& KRUM (1999) for immature loggerheads from captivity. Albumin levels are often elevated during vitellogenesis, due to increased protein synthesis demands (CAMPBELL, 1996). According to WILKINSON (2004), hemodilution by lymph is a possible cause of iatrogenic hypoalbuminemia. That author reported the diluted and pale appearance of blood in case of lymphatic contamination. In this study all samples were examined at time of collection and appeared thick and dark red, thus apparently lymph free.

Relatively higher levels of globulin $(2.6 \mathrm{~g}$ $\left.\mathrm{dL}^{-1} \pm 0.59\right)$ were found when compared to WHITAKER \& KRUM (1999) for captive juvenile turtles and to AGUIRRE \& BALAZS (2000) for $\boldsymbol{C}$. mydas. Higher serum globulin values have been reported by BOLTEN
\& BJORNDAL (1992) for juvenile $\boldsymbol{C}$. mydas from the Bahamas (3.6 $\left.\mathrm{g} \mathrm{dL}^{-1} \pm 0.7\right)$ and by GICKING et al. (2004) $\left(3.8 \mathrm{~g} \mathrm{dL}^{-1}\right)$. According to them, this hyperglobulinemia may be associated to chronic parasite infection, suggesting that, based on body condition and nestbuilding activity, the general health of the turtles in this study was good.

The average of Albumin:Globulin (A:G) ratio $(0.5 \pm 0.20)$ was similar to the results obtained by AGUIRRE \& BALAZS (2000) for healthy green turtles and not far from GICKING et al. (2004) for loggerheads. However, the A:G relation is not a widely used parameter in the clinical evaluation of sea turtles.

Urea values ranged from 11 to $70 \mathrm{mg} \mathrm{dL}^{-1}$ (mean 35.25 $\mathrm{mg} \mathrm{dL}^{-1} \pm 13.50$ ) and were similar to those reported by CAMPBELL (1996) (20-80 $\left.\mathrm{mg} \mathrm{dL}^{-1}\right)$ for adult individuals of $\boldsymbol{C}$. caretta, $\boldsymbol{C}$. mydas, E. imbricata and L. kempi, outside reproductive period. Based on this, it can be assumed that reproduction itself does not alter the urea values. WYNEKEN et al. (2006) reported higher urea values for young loggerheads. Breeding

Table 2 - Mean, standard deviation and reference interval of the variables CCL (curved carapace length), CCW (curved carapace width) and WEIGHT of free-ranging nesting females $\boldsymbol{C}$. caretta $(\mathrm{n}=28)$, Campos of Goytacazes, RJ.

\begin{tabular}{lrccr}
\hline Variables & Mean & Standard deviation & Minimum & Maximum \\
\hline CCL $(\mathrm{m})$ & 1.01 & 0.05 & 0.86 & 1.12 \\
CCW $(\mathrm{m})$ & 0.92 & 0.04 & 0.82 & 1.02 \\
Weight $(\mathrm{kg})$ & 119.20 & 19.04 & 71.7 & 168.1 \\
\hline
\end{tabular}

Ciência Rural, v.41, n.1, jan, 2011. 
females leave foraging areas, thus reduce or even cease feeding, in the period preceding nesting activity, only to return at the end of the breeding season. This may explain the lower urea values found in this study. BONNET (1979) correlated the hyporexia observed in this period with lower urea values.

The creatinine concentration $(0.5 \mathrm{mg} \mathrm{dL}$ $\left.{ }^{1} \pm 0.15\right)$ is normally low in reptiles $\left(<1 \mathrm{mg} \mathrm{dl}^{-1}\right)$ (WYNEKEN et al., 2006), since it is not actively secreted nor reabsorbed by the kidney tubules (WILKINSON, 2004). The mean sodium levels were $147 \mathrm{mEq} \mathrm{L}^{-1}( \pm 14.05)$, similar to reports from STAMPER et al. (2005) for migratory loggerheads in North Carolina, as a result, in both cases, of decreased food intake. The sodium and potassium values obtained by WHITAKER \& KRUM (1999) for captive juvenile loggerheads were higher as the animals were fed daily. The mean potassium concentration was $4.2 \mathrm{mEq} \mathrm{L}^{-1}( \pm 0.91)$, similar to CAMPBELL (1996) and BOLTEN et al. (1992). Sodium and potassium levels may be altered by the intermittent activity of salt glands. Additionally, WILKINSON (2004) suggested decreased food intake as an explanation for reduced potassium levels.

Concerning mean calcium values $(9.9 \mathrm{mg}$ $\left.\mathrm{dL}^{-1} \pm 1.11\right)$, they were high when compared to other sea turtles. However, according to WILKINSON (2004), calcium is mobilized for egg formation during the reproductive period. DEEM et al. (2006) also found elevated calcium and phosphorus levels in a population of nesting leatherbacks.

The mean phosphorus values $(7.9 \mathrm{mg}$ $\mathrm{dL}^{-1} \pm 1.85$ ) were similar to CAMPBELL (1996) for adults from four different species of sea turtles. The average of Ca:P ratio (1.3) was compatible with DIVERS (2000), who established a $\mathrm{Ca}: \mathrm{P}$ ratio greater than 1.0 for healthy reptiles.

ALP activity (13.5IU L L $1 \pm 4.69)$ was similar to that suggested by BOLTEN et al. (1992) for loggerheads. However, WHITAKER \& KRUM (1999) found higher serum activities for captive juvenile loggerheads (73.9IU L $\mathrm{I}^{-1} \pm 37$ ), and so did BOLTEN \& BJORNDAL (1992) for wild juvenile $\boldsymbol{C}$. Mydas (43IU L ${ }^{-1} \pm 16$ ). According to CAMPBELL (1996), ALP is associated with increased osteoblastic activity. Based on this information, it is probable that animals in development stage show higher enzymatic levels, since osteoblasts are responsible for bone matrix synthesis. Sick $\mathbf{L}$. kempi sampled by WHITAKER \& KRUM(1999) at the New England Aquarium had extremely high ALP activities (465.3IU L L ${ }^{-1} \pm 306$ ) due to their clinical conditions. Although ALP is widely distributed in reptile body, literature suggests that it can be found in organs such as bones and reproductive tract (WILKINSON, 2004).
Thus damage to these systems can raise the enzyme levels. The ALT concentration (14IU L $\left.{ }^{-1} \pm 6.35\right)$ agreed with literature (CAMPBELL, 1996; WILKINSON, 2004). However, the AST activity (151IU L $\left.\mathrm{L}^{-1} \pm 61.86\right)$, was low. Meanwhile, STAMPER et al. (2005) found even lower AST activities for migratory animals (129IU L $\left.{ }^{-1}\right)$ and higher values for resident turtles $\left(206 \mathrm{IU} \mathrm{L}^{-1}\right)$. According to these authors, $33 \%$ of the resident animals had carapace lesions and thickening of the skin, whereas only $10 \%$ of the migratory turtles showed these injuries. As such, they attributed the higher AST values in the resident population to tissue injuries. The present study observed a positive correlation between size variables (weight, curved carapace length and curved carapace width) and ALT $(\mathrm{P}<0.05, \mathrm{n}=28)$ and AST $(\mathrm{P}<0.05 ; \mathrm{n}=28)$ enzymes, suggesting that animals with higher hepatic volume have greater enzyme activity. It is relevant to mention that no studies correlating these parameters were found in literature. In chelonians, factors expected to have a significant effect upon hepatic transaminases includes liver or muscular diseases(WILKINSON, 2004; DIVERS, 2000). These factors, however, have not influenced AST and ALT values in this study, since nesting females are generally in good health and capable of reproducing. Additionally, health assessment should take into account the relationship between biochemistry values and body size in order to obtain reliable results and avoid erroneous interpretation of the animal's general condition.

The serum GGT activity ranged between 0.1 and $2.4 \mathrm{IU} \mathrm{L}^{-1}$ (mean $\left.0.72 \mathrm{IU} \mathrm{L}^{-1} \pm 0.67\right)$. These values are similar to DIVERS (2000), although GGT is not a parameter frequently used to evaluate sea turtles health conditions (WILKINSON, 2004), since it is normally low(DIVERS, 2000).

Mean amylase activity was $627 \mathrm{IU} \mathrm{L}^{-1}( \pm 232)$, falling within the range from DEEM et al. (2006) for leatherback nesting females from the Republic of Gabon. The average activity found by DEEM et al. (2003) for loggerhead nesting females in the Caribbean was $623.5 \mathrm{IU} \mathrm{L}^{-1}( \pm 150.1)$. Additionally, DEEM et al. (2009) found higher amylase activities for nesting loggerheads (407IU L ${ }^{-1} \pm 131$ ) than for foraging (263IU $\left.\mathrm{L}^{-1} 99\right)$ or stranded (180IU L $\left.{ }^{-1} \pm 106\right)$ individuals of the same species. This enzyme could possibly be influenced by hormonal factors during the reproductive period. However, further research is required in order to confirm this hypothesis.

The Cholesterol $\left(247 \mathrm{mg} \mathrm{dL}^{-1} \pm 48\right)$ and triglycerides $\left(580 \mathrm{mg} \mathrm{dL}^{-1} \pm 230\right)$ concentrations were significantly higher than in literature. DERICKSON (1976) noted that, due to vitellogenesis, endogenous 
cholesterol and triglycerides levels are typically increased in nesting females. BONNET (1979) observed that fasting sea turtles showed increased concentrations of blood lipids associated to the catabolism of energy reserves. As such, it was suggested that increased levels of serum lipids are a result of reduced food intake and vitellogenesis by nesting females.

Mean uric acid values ranged between $0.3 \mathrm{mg} \mathrm{dL}^{-1}$ and $1.2 \mathrm{mg} \mathrm{dL}^{-1}$ (mean $0.62 \mathrm{mg} \mathrm{dL}^{-1} \pm 0.21$ ). BOLTEN \& BJORNDAL (1992) found higher values in juvenile green turtles $\left(1.5 \mathrm{mg} \mathrm{dL}^{-1} \pm 0.6\right)$ because young C. mydas are primarily carnivores and according to literature, carnivorous reptiles have higher uric acid blood levels.

\section{CONCLUSION}

It was concluded that the free-ranging nesting $\boldsymbol{C}$. caretta showed significant variation in their biochemical profile due to reproductive output. Changes in calcium, phosphorus, cholesterol and triglyceride levels were related to vitellogenesis and egg formation. The obtained values were compared with reference physiological levels for breeding and non-breeding turtles.

Although it is important to monitor health status of a population, there is little published information regarding sea turtles biochemical profiles. Further studies are needed to provide more understanding of this subject.

In summary, this study has characterized, for the first time, the biochemical profile of $\boldsymbol{C}$. caretta nesting females from the northern state of Rio de Janeiro. The data presented here may be useful as reference in the assessment of health and disease of loggerhead populations from southeastern Brazil. In addition, this study might contribute to the rehabilitation of sick individuals and hence, to their reintroduction in the wild.

\section{ACKNOWLEDGEMENTS}

We acknowledge Projeto TAMAR-ICMBio and CAD for the technical support and CAPES for the financial support.

\section{REFERENCES}

AGUIRRE, A.A.; BALAZS, G.H. Blood chemistry values of green turtles, Chelonia mydas, with and without fibropapillomatosis. Comparative Haematology International, v.10, n.3, p.132$137,2000$.

BAPTISTOTTE, C. et al. Reproductive biology and conservation status of the loggerhead sea turtle $($ C. Caretta $)$ in
Espírito Santo state, Brazil. Chelonian Conservation and Biology - International Journal of Turtle and Tortoise Research, v.4, n.3, p.523-529, 2003.

BJORNDAL, K.A.; JACKSON, J.B.C. Roles of sea turtles in marine ecosystems: reconstructing the past. In: LUTZ, P.L. et al. The biology of sea turtles. Boca Raton, Florida: CRC, LLC, 2003. V.2, p.259-274.

BOLTEN, A.B.; BJORNDAL, K.A. Blood profiles of a wild population of green turtles (Chelonia mydas) in the southern Bahamas: size-specifics and sex-specifics relationships. Journal of Wildlife Diseases, v.28, n.3, p.407-413, 1992.

BOLTEN, A.B. et al. Effects of anticoagulant and autoanalyzer on blood biochemical values of loggerhead sea turtles $(\boldsymbol{C}$. caretta). American Journal of Veterinary Research, v.53, n.12, p.2224-2227, 1992.

BONNET, B. Influence of the nutritional conditions on the organic composition of blood and urine in the juvenile sea turtle Chelonia mydas. Aquaculture, v.16, p.253-260, 1979.

CAMPBELL, T.W. Sea turtle rehabilitation. In: MADER, D.R. Reptile medicine and surgery. Philadelphia, Pennsylvania: Saunders, 1996. 512p. Section VII, cap.57, p.427-436.

DEEM, S.L. et al. Sea turtle health assessment program in the Caribbean and Atlantic. In: SEMINOFF, J.A. Proceedings of the Twenty-Second Annual Symposium on Sea Turtle Biology and Conservation. Miami, FL: NOAA Technical Memorandum NMFS-SEFSC-503, 2003. 309p. p.65-66.

DEEM, S.L. et al. Blood values in free-ranging nesting leatherback sea turtles (Dermochelys coriacea) on the coast of the Republic of Gabon. Journal of Zoo and Wildlife Medicine, v.37, n.4, p.464-471, 2006. Available from: http:/ /www.bioone.org/doi/abs/10.1638/05-102.1 journalCode=zamd. Accessed: Feb. 11, 2009. doi: 10.1638/05-102.1.

DEEM, S.L. et al. Comparison of blood values in foraging, nesting, and stranded loggerhead turtles $(\boldsymbol{C}$. caretta) along the coast of Georgia, USA. Journal of Zoo and Wildlife Medicine, v.45, n.1, p.41-56, 2009.

DERICKSON, W.K. Lipid storage and utilization in reptiles. American Zoology, v.16, p.711-723, 1976.

DIVERS, S.J. Reptilian renal and reproductive disease diagnosis. In: FUDGE, A.M. Laboratory medicine - Avian and exotic pets. Philadelphia: Saunders, 2000. 486p. Section two, cap.25, p.217-222.

FEEMA. Perfil ambiental do Município de Campos. Rio de Janeiro: Gráfica da FEEMA, 1993. 146p.

GICKING, J.C. et al. Plasma protein electrophoresis of the atlantic loggerhead sea turtle, C. Caretta. Journal of Herpetological Medicine and Surgery, v.14, n.3, p.13-18, 2004.

KAKIZOE, Y. et al. Successive changes of hematologic characteristics and plasmachemistry values of juvenile loggerhead turtles $(\boldsymbol{C}$. caretta). Journal of Zoo and Wildlife 
Medicine, v.38, p.77-84, 2007. Available from: <http:// www.bioone.org/doi/abs/10.1638/05-096.1>. Accessed: Jan. 5, 2009. doi: 10.1638/05-096.1.

KRATZ, A. et al. The plasma protein. In: McCLATCHEY, K. D. Clinical laboratory medicine. 2.ed. Philadelphia: Lippincott Williams \& Wilkins, 2002. p.263-280.

MARCOVALDI, M.A.; CHALOUPKA, M. Conservation status of the loggerhead sea turtle in Brazil: an encouraging outlook. Endangered Species Research, v.3, p.133-143, 2007 Available from: <http://www.int-res.com/abstracts/esr/v3/n2/ p133-143/>. Accessed: Jan. 5, 2009. doi: 10.3354/esr003133.

STAMPER, A.M. et al. Relationship between barnacle epibiotic load and hematologic parameters in loggerhead sea turtles $(\boldsymbol{C}$.

Caretta), a comparison between migratory and residential animals in Pamlico Sound, North Carolina. Journal of Zoo and Wildlife Medicine, v.36, n.4 p.635-641, 2005. Available from: <http://www.bioone.org/doi/abs/10.1638/04-074.1 >. Accessed: Feb. 11, 2007. doi: 10.1638/04-074.1.

WHITAKER, B.R.; KRUM, H. Medical management of sea turtles in aquaria. In: FOWLER, M.E.; MILLER, R.E. Zoo \& Wild animal medicine. Philadelphia: Saunders, 1999. V.4, p.217-231.

WILKINSON, R. Clinical pathology. In: MCARTHUR, S. etal. Medicine and surgery of tortoises and turtles. Oxford: Blackwell, 2004. 578p. Cap.7, p.141-186.

WYNEKEN, J. et al. Medical care of sea turtles. In: MADER, D.R. Reptile medicine and surgery. 2.ed. Missouri: Saunders Elsevier, 2006. 1442p. Cap.76, p.972-1007. 